\section{No evidence for mosaicism in Silver-Russell syndrome}

EDITOR-Silver-Russell syndrome (SRS) is a condition characterised by pre- and postnatal growth restriction, triangular facies, and limb and truncal asymmetry. ${ }^{12}$ The aetiology of the syndrome is heterogeneous and there is no clearly established Mendelian basis. A number of chromosomal abnormalities are associated with the SRS phenotype in a minority of cases. To date, 37 cases of maternal uniparental disomy for chromosome $7(\operatorname{mUPD}(7))$ have been reported, representing approximately $10 \%$ of all cases. $^{3-18}$

Five mUPD(7) probands were found to show heterodisomy for the complete length of chromosome 7 , ruling out the exposure of a mutant recessive gene as the basis of SRS. ${ }^{19}$ These findings indicate that one or more genes on chromosome 7 are imprinted and involved in the pathogenesis of the syndrome. Lack of a paternal gene(s) expression could result in the syndrome, as could the overexpression of a maternal gene involved in growth inhibition. Recently, two unrelated SRS probands with maternal duplications of $7 \mathrm{p}$ have been reported defining a candidate gene region that may contain the gene(s) responsible for the phenotype associated with $\operatorname{mUPD}(7) .^{2021}$ In addition, a single case of partial $\operatorname{mUPD}(7)$ has been reported with biparental inheritance for the majority of the chromosome, with $\operatorname{mUPD}(7)$ 7q32qter when analysed using fluorescent microsatellite PCR. ${ }^{22}$ This indicates that there are at least two imprinted regions on chromosome 7 that are involved in the pathogenesis of SRS.

It is possible that certain features of the $\operatorname{mUPD}(7)$ SRS phenotype, particularly the asymmetry, could result from an undetected mosaicism for chromosome 7 . This may be analogous to mosaicism for $\mathrm{pUPD}(11)$, which is thought to be the cause of hemihypertrophy seen in BeckwithWiedemann syndrome (BWS). ${ }^{23} 24$

It has clearly been established that the UPD in SRS and BWS arise by different mechanisms. All reported BWS cases of pUPD(11) are isodisomic, resulting in a UPD/normal cell mosaic, most likely occurring from a postzygotic mitotic non-disjunction. In contrast, most reported cases of $\mathrm{mUPD}(7)$ SRS probands exhibit mixed hetero/isodisomy, and are most likely to arise from meiosis I non-disjunction followed by trisomic rescue owing to heterodisomy at the centromeres. Chromosomal mosaicism has previously been ruled out in the two cases of SRS presenting with cystic fibrosis, the latter resulting from unmasking of the maternal recessive CFTR mutation by isodisomy. $^{34}$

Any mosaicism in the cases of heterodisomy would involve both trisomic and UPD cell lines. Four cases of mUPD(7) heterodisomy have been shown to have arisen from trisomic rescue, with mosaicism for trisomy 7 confined to the placenta. ${ }^{725}$ Evidence for an association between SRS and potential mosaicism has been found in a case of maternal long arm and paternal short arm isodisomy for chromosome $7 .^{26}$ There has also been one reported case of an asymmetrical mUPD(7) SRS proband with a mosaic partial paternal ring chromosome $7 .{ }^{16}$ However the function of this ring has not been established. ${ }^{27}$

To test the hypothesis that the SRS phenotype may result from low level mosaicism in the cases of $\operatorname{mUPD}(7)$, we used a similar Southern blot strategy as originally reported by Henry et $a l^{23}$ to show mosaicism in $\mathrm{pUPD}(11) \mathrm{BWS}$ to investigate three SRS probands with $\operatorname{mUPD}(7)$. High molecular weight DNA was extracted from lymphocytes and fibroblasts for two of the mUPD(7) SRS probands and one non-mUPD(7) SRS proband with lateral asymmetry. In addition, DNA was extracted from lymphocytes for the third mUPD(7) SRS and all parents (probands previously described by Preece et $a l,{ }^{11}$ Preece et $a l,{ }^{19}$ and Russo et $a l^{18}$ ). The two heterodisomic mUPD(7) SRS probands reported by Preece et $a l^{11}{ }^{19}$ were growth restricted but were not asymmetrical. The heterodisomic mUPD(7) SRS proband reported by Russo et $a l^{18}$ presented with both growth restriction and lateral asymmetry. Six $\mu \mathrm{g}$ of DNA was digested with 30 units of Hinf1 (Promega) for six hours at $37^{\circ} \mathrm{C}$, electrophoresed on $0.8 \%$ agarose gel overnight, then blotted onto a Hybond N+ filter (Amersham). Filters were hybridised with the D7S22 VNTR probe $(\mathrm{PIC}=0.97)$ to detect the inheritance of parental alleles. DNA probes were radiolabelled with $\left[\alpha^{32} \mathrm{P}\right] \mathrm{dCTP}$ using a nick translation kit (Amersham). Hybridisation was carried out overnight and the filters were washed down with increasing stringency to $0.5 \times \mathrm{SSC} / 0.1 \%$ SDS and exposed to autoradiographic film (Kodak) for three weeks at $-80^{\circ} \mathrm{C}$ so that the presence of any paternal bands could be detected.

Fluorescence in situ hybridisation (FISH) was performed on cultured lymphoblasts and fibroblasts for one mUPD(7) SRS proband and one non-mUPD(7) SRS proband (probands 2 and 4) using standard methods. The cells were probed with chromosome $7 \mathrm{p}$ specific PAC probes containing GRB10 (RP1-108E23) and EGFR (RP1-069I12). Standard miniprepped DNA was nick translated with the direct incorporation of either Spectrum Green or Spectrum Red (Vysis) following the manufacturer's protocol.

Using the 7q36 D7S22 VNTR DNA marker, three $\operatorname{mUPD}(7)$ probands and one non-mUPD(7) SRS control proband and both parents were genotyped by Southern blot analysis. In the three $\operatorname{mUPD}(7)$ probands, direct examination with D7S22 from overexposed Southern blots failed to disclose the presence of paternal alleles. Since the Southern blot technique can only detect mosaicism as low as $10-15 \%$ (unpublished observation), FISH was performed on single nuclei to detect lower levels of mosaicism, in preference to fluorescence PCR reported by Slater et al. ${ }^{24}$ FISH investigations of 200 nuclei also failed to show any potential mosaicism.

To overcome the problem that studies solely on lymphocyte DNA would not rule out tissue specific mosaicism, fibroblasts were also studied where possible. No evidence for mosaicism was found in either cell line in any of the $\operatorname{mUPD}(7)$ SRS probands studied. Studies using skeletal related tissues would have been preferred, but were unavailable.

As it is likely that the mUPD arose from trisomic rescue, it is probable that their placentas were mosaic. The possibility that CPM may influence the phenotypic prenatal growth failure has previously been addressed. Kalousek et $a l^{28}$ reported a study of 14 pregnancies with CPM for trisomy 7. DNA analysis in nine cases showed that the fetal 
UPD was present in only one case whereas the other eight were biparental. One trisomy resulted from meiosis non-disjunction and was associated with the fetal UPD. The infant with the UPD presented with severe IUGR. The other eight cases with biparental inheritance had normal birth weights. This provides evidence that intrauterine growth is not affected by the presence of a trisomic cell line for chromosome 7 in the placenta, therefore making it unlikely that CPM is responsible for the significant growth restriction seen in probands with $\operatorname{mUPD}(7)$.

The findings we report here encourage continued research into the molecular basis of SRS as a consequence of disrupted imprinting. We have presented evidence against somatic mosaicism in three $\operatorname{mUPD}(7)$ probands in two different tissues using both Southern blot and FISH analyses. Comparisons were also made of a case of non-mUPD(7) SRS with lateral asymmetry and no mosaicism was observed.

This work was supported by funding from Children Nationwide (DM) and the Dunhill Medical Trust (MH)

DAVID MONK*+ MEGAN HITCHINS* SILVIA RUSSO MICHAEL PREECE† PHILIP STANIER* GUDRUN E MOORE*

^Institute of Reproductive and Developmental Biology, Imperial College School of Medicine, Hammersmith Campus, Du Cane Road, London, W12 ONN, UK

†Institute of Child Health, University College London, 30 Guilford Street, London WC1N 1EH, UK

$\ddagger$ Molecular Genetics Laboratory, Italian Auxological Institute, Milan, Italy

Correspondence to: D Monk, d.monk@ic.ac.uk

1 Silver HK, Kiyasu W, George J, Deamer WC. Syndrome of congenital hemihypertrophy, shortness of stature, and elevated urinary gonadotrophins. Pediatrics 1953;12:368-76.

2 Russell A. A syndrome of intrauterine dwarfism recognised at birth with craniofacial dysostosis, disproportionate short arms and other anomalies. Proc R Soc Med 1954;47:1040-4.

3 Spence J, Perciaccante R, Grieg G, Huntington F, Ledbetter D, Hejtmancik J, Pollack, M, O'Brien W, Beaudet A. Uniparental disomy as a mechanism for human genetic diseases. Am F Hum Genet 1988;42:21 7-26.

4 Voss R, Ben-Simon E, Avital A, Godrey S, Zlotogora J, Dagan J, Tikochinski Y, Hillel J. Isodisomy for chromosome 7 in a patient with cystic fibrosis: could uniparental disomy be common in humans? Am f Hum Genet 1989; 45:373-80.

5 Spotila L, Sereda L, Prockop D. Partial isodisomy for maternal chromosome 7 and short stature in an individual with a mutation at the COLIA2 locus. Am f Hum Genet 1992;51:1396-405.

6 Kotzot D, Schmitt S, Bernasconi F, Robinson W, Lurie I, Ilyina H, Mehes K, Hamel B, Otten B, Hergersberg M, Werder E, Schonle E, Schinzel A. Uniparental disomy in Silver Russell syndrome and primordial growth Uniparental disomy in Silver Russell syndr

7 Langlois S, Yong S, Wilson R, Kwong L, Kalousek D. Prenatal and postnatal growth failure associated with maternal heterodisomy for chromosome 7. F Med Genet 1995;32:871-5.
8 Shauman C, Weksberg R, Nedelcu R, Northey A, Scherer S. Chromosome 7 uniparental disomy in Silver Russell Syndrome. Am 7 Hum Genet 1996;59(suppl):1648.

9 Tariverdian G, Vioglander T, Emmerich D, Bernasconi F, Schinzel A. Uniparental disomy 7 in Silver Russell syndrome. Medgen 1996;8:9-25.

10 Eggermann T, Wollmann H, Kunar R, Eggermann K, Enders H, Kaiser P, Ranke M. Molecular studies of 37 Silver Russell syndrome patients: 19.

11 Preece M, Price S, Davies V, Clough L, Stanier P, Trembath R, Moore G. Maternal uniparental disomy 7 in Silver-Russell syndrome. $\mathcal{F}$ Med Genet 1997;34:6-9.

12 Cogliati F, Russo S, Macchi M, Selicorni A, Bedeschi M, Natacci F, Parini $\mathrm{R}$, Larizza L. Uniparental disomy and PEG1/MEST gene in Silver-Russell syndrome. Eur F Hum Genet 1998;(suppl 1):217.

13 Cuisset L, Le Stunff C, Dunpont J, Vasseur C, Cartigny M, Despert F, Delpech M, Bougnere P, Jeanpierre M. PEG1 expression in maternal disomy of chromosome 7. Ann Genet 1998;40:211-15.

14 Hehr U, Bromme S, Dorr S, Hagemann M, Preiss U, Hansmann I. Silver Russell syndrome and cystic fibrosis caused by maternal uniparental disomy 7. Medgen 1999;11:1-13.

15 Mergenthaler S, Wollmann H, Schartmann B, Eggermann K, Kaiser P, Ranke M, Schwanitz G, Eggermann T. Origin of trisomy 7: studies on the formation of uniparental disomy 7 and a case of confined placental mosaicism for trisomy 7. Medgen 1999;11:200.

16 Miyoshi O, Kondoh T, Tandeda H, Otsuka K, Matsumoto T, Niikawa N. $47, \mathrm{XX}$, UPD(7)mat, $+\mathrm{r}(7)$ mat mosaicism in a girl with Silver Russell syndrome (SRS): possible exclusion of the putative SRS gene from a 7p13-q11 region. F Med Genet 1999;36:326-9.

17 Hannula K, Lipsanen-Nyman M, Hoglund P, Holmberg C, Kere J. Maternal uniparental disomy of chromosome 7 is confined to cases of Silver Russell syndrome in children with growth retardation of unknown etiology. $\mathrm{Am}$ 7Hum Genet 1999;(suppl):A152565:4.

18 Russo S, Bedeschi M, Cogliati F, Natacci F, Giantti A, Parini R, Selicorni A, Larizza L. Maternal chromosome 7 hetero/isodisomy in Silver Russell synLarizza L. Maternal chromosome 7 hetero/isodisomy in Silver Russell syn-
drome and PEG1 biallelic expression. Clin Dysmorphol 2000;9:157-62.

19 Preece M, Abu-Amero S, Ali Z, Abu-Amero K, Wakeling E, Stanier P, Moore G. An analysis of the distribution of hetero- and isodisomic regions of chromosome 7 in five mUPD7 Silver-Russell syndrome probands. $\mathcal{F}$ Med Genet 1999;36:457-60.

20 Joyce A, Sharp A, Walker J, Bullman H, Temple KI. Duplication of 7p11.2p13, including GRB10 and IGFBP1, in a mother a daughter with features of Silver Russell syndrome. Hum Genet 1999;105:273-80.

21 Monk D, Wakeling E, Proud V, Hitchins M, Abu-Amero S, Stanier P, Preece M, Moore GE. Duplication of 7p11.2-p13, including GBR10, in Silver Russell syndrome. Am f Hum Genet 2000;66:36-46.

22 Hannula K, Lipsanen-Nyman M, Kontiokari T, Kere J. A narrow segment of maternal uniparental disomy of chromosome 7q31-pter in Silver Russell syndrome delimits a candidate gene region. Am f Hum Genet 2001;68:24753.

23 Henry I, Puech A, Riesewijk A, Ahnine L, Mannens M, Berldjord C, Bitoun C, Tournade M, Landrieu P, Junien C. Somatic mosaicism for partial isodisomy in Wiedemann-Beckwith syndrome: a post-fertilization event. Eur 7 Hum Genet 1993;1:19-29.

24 Slater R, Elliott M, Welham K, Carrera M, Schofield P, Barton D, Maher E. Mosaic uniparental disomy in Beckwith-Wiedemann syndrome. 7 Med Genet 1994;34:749-53.

25 Kotzot D, Balmer D, Baumer A, Chrzanowska K, Hamel B, Iilina H, Krajewska-Walasek M, Lurie I, Otten B, Schoenle E, Tariverdian G, Schinzel A. Maternal uniparental disomy 7 - review and further delineation of the phenotype. Eur $\mathcal{F}$ Pediatr 2000;159:247-56.

26 Eggerding F, Schonberg S, Chehab F, Norton M, Cox V, Epstein C. Uniparental isodisomy for paternal $7 \mathrm{p}$ and maternal $7 \mathrm{q}$ in a child with growth retardation. Am f Med Genet 1993;55:253-65.

27 Wakeling E, Hitchins M, Stanier P, Monk D, Moore G, Preece M. Silver-Russell syndrome and ring chromosome 7. F Med Genet 2000;37: 380 .

28 Kalousek D, Langlois S, Robinson M, Telenius L, Bernard L, Barrett I, Howard-Peebles P, Wilson R. Trisomy 7 CVS mosacism: pregnancy outcome, placental and DNA analysis in 14 cases. Am F Med Genet 1996; 15:348-52. 